\title{
NOVAS FORMAS DE GESTÃO DA FORÇA DE TRABALHO DO SERVIÇO PÚBLICO BRASILEIRO E SUAS REPERCUSSÕES PARA O ADOECIMENTO MENTAL: UM ESTUDO SOBRE OS SERVIDORES DE UMA INSTITUIÇÃO JUDICIÁRIA
}

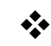 \\ Fernanda Iracema Moura Arnaud \\ Universidade Federal do Pará - UFPA - Brasil \\ Vera Lúcia Batista Gomes \\ Universidade Federal do Pará - UFPA - Brasil
}

\section{Resumo}

Este artigo é resultado de análise efetuada sobre os dados obtidos com a realização de uma pesquisa empírica realizada junto a 22 (vinte e dois) servidores de uma instituição judiciária, problematizada à luz da teoria social crítica. Tem como objetivo analisar as novas formas de gestão da força de trabalho adotadas pelo serviço público brasileiro, a partir dos anos 1990, e suas repercussões para o adoecimento mental de tais trabalhadores. Conclui-se, a partir desse estudo, que essas novas formas de gestão baseadas no chamado modelo de acumulação flexível, orientadas pelas ideias neoliberais, avançam no serviço público, consolidando a lógica privatista e produtivista, antes restrita ao âmbito empresarial, provocando novas formas de precarização do trabalho que repercutem tanto nas condições de vida pessoal/profissional quanto na saúde dos servidores, o que implica, negativamente, no cumprimento da missão das instituições públicas, dentre as quais, na instituição judiciária em estudo.

Palavras-chave: Gestão da Força de Trabalho; Neoliberalismo; Adoecimento mental.

\section{Introdução}

Este artigo é resultado de reflexões e análises efetuadas sobre os dados obtidos com a realização de uma pesquisa empírica que subsidiou a elaboração da dissertação de mestrado ${ }^{1}$ de uma das autoras, bem como nos estudos e debates efetudos no Grupo de Estudos e Pesquisas "Trabalho, Estado e Sociedade na Amazônia", o qual é vinculado ao Programa de Pós-Graduação em Serviço Social - UFPA e congrega estudantes, profissionais e docentes pesquisadores sobre o trabalho na contemporaneidade.

Sabe-se que o trabalho, enquanto atividade prático-social é fonte de toda riqueza produzida (MARX, 1982), no modo de produção capitalista, entretanto, contraditoriamente, é reduzido à sua dimensão abstrata, caracterizada como dispêndio de força humana produtiva, física e intelectual, socialmente determinada voltada para a produção de trabalho excedente ou

\footnotetext{
${ }^{1}$ A mencionada Dissertação teve como objeto de estudo a intervenção profissional do assistente social na saúde mental de servidores públicos de uma instituição judiciária, englobando 03 (três) órgãos (um na região Norte e dois na região Sudeste).
}

Barbarói, Santa Cruz do Sul, n.48, p.<106-134>,jul./dez. 2016 
mais-valia, apropriado pelo capitalista.

$\mathrm{Na}$ base de todo esse processo de valorização, encontra-se a alienação do trabalho, expressa como desefetivação ou exteriorização do trabalhador, uma vez que este se relaciona com o que produz como com um objeto alheio. Trata-se do trabalho em sua forma social ou trabalho abstrato, expresso no fato de que

\begin{abstract}
O trabalho é exterior ao trabalhador, ou seja, não pertence à sua essência, que portanto ele não se afirma, mas se nega em seu trabalho, que não se sente bem, mas infeliz, que não desenvolve energia mental e física livre, mas mortifica a sua physis e arruína a sua mente [...] o seu trabalho [...] não é a satisfação de uma necessidade, mas somente um meio de satisfazer necessidades fora dele [...] a atividade do trabalhador não é a sua auto-atividade. Pertence a um outro, é perda de si mesmo (MARX e ENGELS, 1989, p. 153).
\end{abstract}

Sob este entendimento, Iamamotto (2011, p.71) ratifica que "realizar trabalho é consumir produtivamente um desgaste das atividades vitais do indivíduo durante um determinado tempo, no qual está implicada a totalidade da pessoa individual" [...] "suas capacidades, emoções, ritmos do corpo, faculdades da mente, sua atenção, sua personalidade, seus sentimentos".

Assim, com a finalidade de apropriação cada vez mais crescente de massas de maisvalia, o capital metamorfoseia-se para alcançar seu objetivo - a busca incessante pelo lucro - e sair das crises cíclicas que lhes são inerentes, gerando uma profunda desumanização provocada pelo processo de acumulação de capital, sobretudo nos momentos de crise (MANDEL, 1990).

Nessa lógica, a partir da década de 1970, desencandeou-se o processo de mundialização do capital como uma "nova configuração do capitalismo mundial e dos mecanismos que comandam seu desempenho e sua regulação" (CHESNAIS, 1996, p.13), cuja principal característica é a internacionalização dos capitais produtivo, comercial e financeiro. $\mathrm{Na}$ esfera produtiva, o aspecto essencial da internacionalização se manifesta pela aquisição/fusão de capitais formando grandes grupos capitalistas - os oligopólios, com a expansão de suas filiais (multinacionais e transnacionais), em particular para os países do terceiro mundo, promovendo uma dinâmica de acirrada concorrência entre as empresas constituintes dos grandes grupos que dominam os ramos industriais diferenciados.

Assumem especial relevância, nesse contexto, as inovações tecnológicas e científicas, notadamente nos processos produtivos, assim como as novas estratégias de gestão da força de trabalho, expressas por métodos voltados para a elevação da força produtiva social do 
trabalho, pois, conforme afirmou Marx (1996, p. 256), "toda acumulação torna-se meio de nova acumulação".

Trata-se do trabalho abstrato, expresso no fato de que “(...) se insere na reestruturação política, social e econômica do novo estágio de acumulação" (FREIRE, 2010, p. 39), cujos custos recaem em quase sua totalidade sobre os trabalhadores, ampliando o trabalho terceirizado, a intensificação do trabalho, as perdas salariais, as perdas de direitos sociais e da capacidade de luta dos trabalhadores ou sua atrofia sociopolítica. Há uma expansão das formas de gestão flexibilizada e desregulamentada, embasada no modelo toyotista e de acumulação flexível e, consequentemente, a diminuição da adoção do padrão tayloristafordista, bem como a introdução da forma de regulação social embasada nas ideias neoliberais, privatizante e anti-social (ANTUNES, 2006).

Nesse sentido, reestruturação produtiva e neoliberalismo são faces de um mesmo processo de investida do capital para sobreviver por meio da intensa exploração da força de trabalho e recuperação das taxas de lucro. Como consequência, a precarização do trabalho nos serviços públicos nas últimas décadas tem sido crescente devido: ao avanço da ideologia generalista nas formas de organização do trabalho (polivalência), o que implica sobrecarga de trabalho, em decorrência do número reduzido de servidores; à flexibilização das relações de trabalho (perda de direitos, arrocho salarial e consequente endividamento); à autonomia reduzida no trabalho; à ausência do reconhecimento pelo trabalho realizado e ao controle para o cumprimento de metas, afetando o desempenho e a produtividade dos mesmos.

Desse modo, estas situações podem ser compreendidas no contexto de crise estrutural do capital quando, desde 1990, por imposição das agências multilaterais orientadas pela face econômica e política do ideário neoliberal, no Brasil, o Estado brasileiro passou a adotar tal ideário que impactou de forma drástica o serviço público, implicando no sucateamento das instituições, expresso na falta de recursos e condições precárias de trabalho e no "enxugamento" da máquina pública, pela redução da contratação por concurso público e/ou pelo crescimento de formas de contratação não-estatutárias (funcionários terceirizados, estagiários, trabalhadores temporários). Em síntese: ratifica-se a precarização do trabalho, pelo enxugamento e sucateamento do serviço público, ao mesmo tempo em que ocorre o aumento da demanda pelos serviços e diminuição dos investimentos públicos, comprometendo, assim, a qualidade dos mesmos (IAMAMOTO, 2001).

Como corolário desse processo de precarização do trabalho na cena contemporânea, produz-se profundos rebatimentos na saúde dos trabalhadores, dentre os quais se evidencia 
danos morais, sofrimentos e adoecimentos, particularmente os mentais, pois, conforme expõe Minayo (2013, p. 258-259),

\begin{abstract}
Saúde/doença são também metáforas de explicação da sociedade: de suas anomias, desequilíbrios, medos e preconceitos, servindo como instrumento coercitivo ou libertador para os indivíduos e sua comunidade [...]. É no indivíduo que essas concepções se unificam: é ele que sofre os males ou detém a condição de saúde. As causas de origem, no entanto, expressam-se no plano simbólico, com referência ao social.
\end{abstract}

Sendo assim, as políticas neoliberais contrariam a necessidade de um Estado ativo na organização da economia desses países, pois para a classe que conduz a acumulação global, os mercados liberais são o ideal, tensionando o Estado no que concerne às contradições sociais postas pela relação capital-trabalho, sobretudo no que tange às estratégias de gestão da força de trabalho baseada na cobrança de resultados por meio da imposição de metas de produtividade aos servidores.

Este trabalho está organizado em 05 (quatro) partes, incluindo a introdução e as considerações finais. A segunda parte discute o processo de reestruturação produtiva e as consequentes transfomações no mundo do trabalho, com destaque para as novas formas de gestão da força de trabalho criadas para intensificar o processo de acumulação. A terceira parte explicita o avanço da política neoliberal sobre o serviço público, por meio do processo de Reforma do Estado em curso desde os anos de 1990. A quarta parte demonstra, a partir de pesquisa qualitativa realizada junto a servidores públicos de uma instituição judiciária, as refrações dos processos sociais em curso na saúde do trabalhador, particularmente, no que tange ao novo perfil de morbimortalidade que evidencia a prevalência dos transtornos mentais e comportamentais e das lesões por distúrbios osteomusculares. Ao final, foram efetuadas as considerações que destacam a revelância da presente análise para a gestão dos serviços públicos, em geral, para as equipes de saúde e para o Serviço Social no sentido de estimular um processo de construção cotidiana de novas estratégias que afirmem os direitos sociais e as políticas sociais universais, capaz de reinventar o sentido do público (ALMEIDA, 2004), visando a oferta de serviços públicos de qualidade à população, o que perpassa pela garantia de condições de vida, de trabalho e de saúde dignas aos servidores públicos.

\title{
Reestruturação produtiva e as novas estratégias de gestão da força de trabalho
}

Após a Primeira Guerra Mundial e a grande depressão da década de 1929, o sistema capitalista adotou como estratégia para recuperação das taxas de lucro a forma de organização 
do trabalho taylorista-fordista que buscou aplicar os princípios científicos como meios de aperfeiçomento do processo produtivo e de sua racionalização máxima. Suas principais características envolviam: o controle dos tempos e movimentos do trabalhador, a produção em larga escala, a separação entre concepção e execução, a especialização de cada operário em apenas uma etapa do processo produtivo e a ênfase na figura do gerente, que detinha o conhecimento e fiscalizava os trabalhadores. De maneira sintética, conforme afirmou Antunes:

Podemos indicar que o binômio taylorismo-fordismo, expressão dominante do sistema produtivo e de seu respectivo processo de trabalho, que vigorou na grande indústria, ao longo praticamente de todo o século $\mathrm{XX}$, sobretudo a partir da segunda década, baseava-se na produção em massa de mercadorias, que se estruturava a partir de uma produção mais homogeneizada e enormemente verticalizada (ANTUNES, 2009, p. 38. Grifos do autor).

Nesse período, vivenciou-se os chamados "trinta anos gloriosos" decorrentes de uma crescente prosperidade econômica sob o denominado Welfare State. Na década de 1970, entretanto, diante de uma nova crise do capitalismo contemporâneo os mecanismos de acumulação de capital taylorista-fordista cederam lugar para a adoção de inovadoras estratégias de consumo e de gestão da força de trabalho, inaugurando novas formas de intensificação da exploração dos trabalhadores. Surgiu, assim, a era da acumulação flexível e do sistema de organização da produção de base toyotista, marcadas pela "flexibilidade dos processos de trabalho, dos mercados, dos produtos e padrões de consumo" (HARVEY, 1995, p.140).

Importa mencionar que tais processos sociais tem provocado profundas transformações no mundo do trabalho, dentre as quais o constante aperfeiçoamento das forças produtivas que incidiu no incremento do chamado trabalho morto ou conversão do trabalho vivo em morto pela transferência do saber cognitivo do trabalhador à maquinaria (com o surgimento das chamadas máquinas inteligentes e de softawares avançados). Em consequência, tem-se a crescente imbricação entre trabalho material e imaterial, com a ampliação do trabalho dotado de maior dimensão intelectual, tanto nas indústrias mais informatizadas quanto no setor de serviços, processos ressaltados por diversos autores (ANTUNES, 2006; ALVES, 2011; LOJKINE, 1995), donde se manifesta uma apropriação crescente das capacidades cognitivas e do envolvimento da subjetividade do trabalhador, porém subordinadas à lógica do capital em detrimento do sentido humano genérico do trabalho. 
A flexibilização dos processos e das relações de trabalho ocasionou um crescente movimento de desregulamentação de direitos sociais e trabalhistas, promovendo o crescimento dos trabalhos precarizado, informal, subcontratado, parcial e temporário; a ampliação do assalariamento no setor de serviços; a retração do operariado industrial e o avanço do desemprego estrutural. Nesse cenário de instabilidade, flutuações constantes e de precarização, há de se mencionar ainda o acirramento da competitividade entre os trabalhadores, a queda de seu poder aquisitivo e a fragilização dos sindicatos.

Importa mencionar como características essenciais desse novo modelo de acumulação: a produção ajustada à demanda do mercado; o sistema just-in-time (produzir somente o necessário, sem desperdícos, no tempo certo); os Círculos de Controle da Qualidade (CCQ’s) para garantir a alta qualidade dos produtos; o trabalhador polivalente; a participação no processo produtivo dentro da ordem ou envolvimento cooptado, por meio do qual os próprios trabalhadores controlam a si próprios e uns aos outros, com base em metas e objetivos fixados previamente. Afirma-se, assim, o forte potencial político-ideológico do toyotismo, sobretudo por atingir não apenas a base material da classe operária no processo produtivo, mas sua consciência de classe, valores e capacidade de organização.

Trata-se de uma nova forma de gestão e consumo da força de trabalho que traz sérias consequências para suas condições de vida, de trabalho e de saúde, pois conforme afirmou Alves (2011, p. 112), imbrincado a esse processo, está havendo uma verdadeira "captura" da subjetividade do trabalhador, destacando que o que se busca "capturar" “(...) é o pensamento do trabalhador, operário ou empregado, integrando suas iniciativas afetivo-intelectuais nos objetivos da produção de mercadorias", o que ocorre não apenas na esfera produtiva restrita do local de trabalho, mas também nas instâncias socioreprodutivas.

Desta feita, surgidos no bojo do processo de reestruturação produtiva e da acumulação capitalista na fase de mundialização do capital, a organização do trabalho de base toyotista e todos os seus dispositivos organizacionais (polivalência, produção just-in-time, círculo de controle de qualidade, dentre outros) possuem uma capacidade manipulatória tão ampliada que "tende[m] a dilacerar (e estressar) não apenas a dimensão física da corporalidade viva da força de trabalho, mas sua dimensão psíquica e espiritual (que se manifesta por sintomas psicossomáticos)" (ALVES, 2011, p.114), pois, ainda segundo este autor:

O toyotismo é a administração by stress, pois busca realizar o impossível: a unidade orgânica entre o "núcleo humano", matriz da inteligência, da fantasia, da iniciativa do trabalho como atividade significativa, e a "relação capital" que preserva a dimensão do trabalho estranhado e os mecanismos de controle do trabalho vivo (ALVES, 2011, p. 114). 
Essas transformações no mundo do trabalho reverberam também na atual configuração do setor de serviços, pois este setor hoje, ao contrário da época vivida por Marx, apresenta-se complexo e multifacetado. Para este autor, "serviços não é em geral mais do que uma expressão para o valor de uso particular do trabalho, na medida em que este não é útil como coisa mas como atividade" (MARX, 1975, p. 102). Entretanto, embora seja expressão de valor de uso como atividade, o trabalho no setor de serviços não está isento de ser incorporado à lógica de valorização do capital, pois, a essência da sociedade capitalista é transformar o trabalho improdutivo em produtivo (BRAVERMAN, 1987), ainda que siga a "outros imperativos e determinações, como os serviços jurídico-forenses oferecidos pelo Estado" (SOUZA, 2004, p. 61). Assim, o novo modelo de acumulação flexível e o toyotismo atingiram também o serviço público, particularmente no que tange às estratégias de gestão da sua força de trabalho que seguem a lógica privatista e produtivista com base nas ideias neoliberiais.

\section{Neoliberalismo, reforma do estado e serviço público}

O neoliberalismo é um "fenômeno distinto do simples liberalismo clássico do século passado" (ANDERSON, 1995), tendo surgido após a Segunda Guerra Mundial, em regiões da Europa e da América do Norte sob a hegemonia do capitalismo. Seu formulador foi Friedrich Hayek e sua principal direção doutrinária centrava-se na forte crítica à qualquer tendência mais intervencionista do Estado, de forma que condenava possíveis limitações estatais aos mecanismos de mercado, consideradas ameaças à liberdade econômica e política.

Entretanto, foi somente com a crise do modelo fordista-keynesiano, em 1973, que as ideias neoliberais ganharam fôlego expandindo-se, inicialmente, para a Inglaterra, os Estados Unidos, os países do Norte da Europa, e, posteriormente, apesar das resistências, para o Sul europeu, para a Austrália, a Nova Zelândia, o Leste europeu e a América Latina, em um período de longa e profunda recessão em todo o mundo capitalista, com baixas taxas de crescimento e elevado índice inflacionário (IDEM).

As raízes da crise apontadas pelos defensores de tal doutrina encontravam-se nas medidas social-liberais, sobretudo, na força excessiva dos sindicatos que pressionavam o aumento dos salários e na pressão das reivindicações operárias para aumentar os gastos sociais do Estado. As soluções propostas envolviam elevação das taxas de juros, contração da emissão monetária, abolição de controles sobre os fluxos financeiros, legislação anti-sindical, 
redução de impostos para altos rendimentos, programas de privatizações, corte nos gastos sociais e redução do papel do Estado.

Segundo BEHRING (2008, p. 127), o neoliberalismo, em nível mundial, “configura-se como uma reação burguesa conservadora e monetarista, de natureza claramente regressiva, dentro da qual se situa a contra-reforma do Estado". Na esteira dessa análise, Coutinho (2008) destaca que a contra-reforma em curso refere-se ao movimento do capital no sentido da restauração de seu poder econômico-político em nível mundial, de que o ideário do neoliberalismo é expressão. Foi assim que surgiram, no final dos anos 80, suas investidas como um "conjunto de propostas de políticas e reformas (...) para a salvação latinoamericana" (UGÁ, 2004, p. 56), expressas no Consenso de Washington, diante da crise capitalista na periferia do sistema que se manifestava por meio da estagnação econômica, dos processos inflacionários e do grave endividamento externo dos países. Dentre tais recomendações, ratificou-se que o Estado deveria mudar, "leia-se realizar reformas" para se adequar ao mundo em mutação e "aumentar sua eficiência" (IDEM, p. 56).

Como consequência, Almeida (2004, p. 39) refere-se que, desde os anos 1990, estamos assistindo "à destruição de uma civilização baseada na igualdade republicana dos direitos e associada à existência do serviço público", determinada pelo avanço das políticas de inspiração neoliberal, as quais propagam a necessidade da redução da intervenção estatal nas políticas sociais (saúde, educação, previdência) e a privatização dos serviços e das atividades econômicas. Acrescenta o referido autor que está em curso a consolidação da tendência tecnocrática a qual reduz a missão estatal, transformando-a do patamar de uma intervenção voltada à defesa do sentido público e coletivo das ações estatais, para ações que permitem apenas a passagem da situação de carência para a de consumo, da situação de pobreza para a aquisição de bens pela maioria da população.

No bojo do avanço do ideário neoliberal, o conjunto dessas transformações afeta também a gestão pública no Brasil, cuja maior expressão ocorreu no governo do presidente Fernando Henrique Cardoso que lançou a base institucional para sua consecução, consubstanciada no Plano Diretor da Reforma do Estado, aprovado pela Emenda Constitucional $n^{\circ} 19$, de 19/06/1995. Tal documento estabelece como condições inadiáveis para a estruturação do Estado brasileiro:

(1) o ajustamento fiscal duradouro; (2) reformas econômicas orientadas para o mercado, que, acompanhadas de uma política industrial e tecnológica, garantam a concorrência interna e criem as condições para o enfrentamento da competição internacional; (3) a reforma da previdência social; (4) a inovação dos instrumentos de política social, proporcionando maior abrangência e promovendo melhor qualidade para os serviços sociais; e (5) a reforma do aparelho do Estado, com 
vistas a aumentar sua "governança", ou seja, sua capacidade de implementar de forma eficiente políticas públicas (BRASIL, 1995, p. 11).

A reforma do aparelho de Estado foi centrada em três dimensões: a institucional-legal, voltada para a reforma do sistema jurídico e das relações de propriedade; a cultural, pautada na transição de uma cultura burocrática para uma cultura gerencial; e, por fim, a terceira dimensão, a qual concebe a gestão pública a partir do aperfeiçoamento da administração burocrática existente e da incorporação da administração gerencial, incluindo os aspectos de modernização da estrutura organizacional e dos métodos de gestão (IDEM). No lastro desse processo reformista, é necessário, entretanto, distinguir a reforma do Estado enquanto processo de dimensões amplas, econômicas, políticas e sociais, componente do movimento de reestruturação do capitalismo, em nível mundial, e a reforma do aparelho de Estado.

Esta reforma refere-se ao conjunto de medidas levadas a efeito, no Brasil, com vistas a tornar a administração pública mais eficiente. Define-se a partir da implantação de novas práticas de gestão da coisa pública, uma vez que, segundo diagnóstico expresso na emenda supracitada, a crise do Estado tinha outra natureza, sendo encarada como uma crise fiscal, "de esgotamento do modelo estatizante de intervenção na economia - do qual são expressões o Welfare State, o estatismo comunista e o desenvolvimento com substituição de importações da periferia" (BEHRING, 2008, p. 177).

Este fato ocorreu, sobretudo, após a promulgação da Constituição Federal de 1988 que provocou, segundo os neoliberais, um encarecimento significativo da máquina pública. Sendo assim,

[...] para uma reforma consistente do aparelho do Estado necessita-se, hoje, mais que um mero rearranjo de estruturas. A superação das formas tradicionais de ação estatal implica descentralizar e redesenhar estruturas, dotando-as de inteligência e flexibilidade, e, sobretudo desenvolver modelos gerenciais para o setor público capazes de gerar resultados (BRASIL, 1995, p. 40).

Segundo Dain e Soares (1998, p. 72), tal reforma “(...) escolhe como bode expiatório o gasto fiscal, e como vilão, o funcionalismo público, na verdade partes essenciais de qualquer processo de Reforma”. Por conseguinte, iniciou-se, no Brasil, um processo de introdução, no setor público, de elementos da administração privada (Dal Rosso, 2008), com a adoção do modelo da Administração Pública Gerencial, voltada à qualidade e produtividade, uma vez que "o Estado brasileiro é caracterizado como rígido, lento, ineficiente e sem memória administrativa" (BEHRING, 2008, p. 177). Desta feita, o aparelho do Estado incorporou princípios de eficiência e qualidade na prestação de serviços públicos, de orientação para o 
cidadão-cliente, de controle por resultados e da competição administrada. Entretanto, manteve algumas características da forma de administração burocrática como a avaliação sistemática, a recompensa pelo desempenho e a capacitação permanente (BRASIL,1995).

No âmbito do Judiciário brasileiro, como núcleo estratégico do Estado, a reforma foi iniciada em 2004, tendo como marco a Emenda Constitucional no 45 e como objetivo central a modernização da estrutura rígida e burocrática desse Poder, no sentido de combater a sua morosidade, ineficiência e falta de transparência (RENAUT, 2005, apud SENA, SILVA, LUQUINI, 2012). Nesse contexto, foi criado o Conselho Nacional de Justiça, órgão inserido na estrutura do Poder Judiciário, com função de fiscalização e controle da atividade jurisdicional, o qual tem desempenhado papel destacado na implementação de tais mudanças. Desse modo, as principais diretrizes da reforma do Judiciário são: o planejamento estratégico e a proposição de políticas, modernização tecnológica, ampliação do acesso à justiça e garantia do respeito às liberdades públicas e execuções penais; a serem implementadas por um plano de metas que define indicadores de eficiência, de produtividade e de qualidade para o referido Poder, no sentido de torná-lo mais efetivo (idem).

A propósito, Di Pietro (2002, p. 83, apud SENA, SILVA, LUQUINI, 2012, p. 72) refere-se ao princípio constitucional da eficiência, o qual objetiva não somente desrespeito ao modo de "organizar, estruturar [e] disciplinar a Administração Pública" no sentido de alcançar melhores resultados, mas também envolve o modo de atuação do agente público, "do qual se espera o melhor desempenho possível de suas atribuições”. Contudo, a cobrança por melhores resultados, além de mudanças substanciais nas estruturas dos órgãos judiciários, trazem algumas implicações para a organização do trabalho nessa instância de Poder que repercutem na saúde dos servidores.

Alves e Palmela (2011), ao analisarem os impactos provocados pela reestruturação produtiva na estrutura social do serviço público, ressaltam que a ofensiva capitalista não compreende somente o enxugamento da máquina pública, mas diz respeito, sobretudo "a inovações tecnológicas e organizacionais de impacto, isto é, à introdução de novas tecnologias e "choque de gestão" que intensificam o trabalho estranhado com perdas e danos irreparáveis à saúde do trabalhador" (IDEM, p. 50-51) (Grifos dos autores).

Logo, em um contexto marcado pela crescente judicialização ${ }^{2}$ dos conflitos sociais e de intensificação do trabalho no Poder Judiciário, pressões pela produtividade do trabalho,

\footnotetext{
${ }^{2}$ A judicialização ou tribunalização dos conflitos sociais refere-se ao complexo fenômeno de transformar em uma questão administrativa e institucionalizada questões sociais cujas origens estão nas relações sociais, ou seja, quando o Judiciário é acionado pelos "excluídos" para dirimir conflitos relacionados ao processo de expropriação da riqueza e dos benefícios sociais (FARIA, 2001).
} 
aliadas a um contexto marcado por relações de trabalho rígidas e hierarquizadas, "de cariz autocrático características da organização do trabalho nas esferas de poder do Estado brasileiro" (IDEM, p. 53), evidenciam outra forma de precarização do trabalho nessa esfera. Trata-se da precarização do trabalho relacionada ao processo saúde-adoecimento dos trabalhadores resultante da "voracidade da reestruturação produtiva - traduzida na pressão por metas e intensificação das tarefas" (idem), bem como em outras estratégias, como a definição de avaliação de desempenho individual dos servidores ${ }^{3}$.

Da mesma forma, Zanin et. al. (2015) destaca que uma das facetas relacionadas ao avanço da lógica privatista sobre o serviço público é o choque de cultura, pois às estruturas burocráticas arcaicas e patrimonialistas deste serviço começaram a impor mecanismos de funcionamento da administração privada, gerando ações e programas que modificaram os processos de trabalho e as relações entre as pessoas, tanto entre seus próprios servidores, quanto destes com o público atendido, gerando sérias consequências para a vida pessoal, social e profissional dos mesmos.

Com efeito, segundo Ribeiro (2008 apud ALVES E PALMELA, 2011), nos anos 2000, no Judiciário, surgem com maior frequência problemas de insatisfação no trabalho e adoecimento dos servidores, ocorrendo uma grande incidência de traumas e adoecimentos decorrentes das relações de trabalho autoritárias e estressantes ou do cumprimento de ordens judiciais de caráter perverso, a exemplo das ações de reintegração de posse, que despejam famílias carentes, no caso dos oficiais de justiça (RIBEIRO, 2009).

Na mesma linha de análise, ao apresentarem as repercussões do trabalho na saúde dos servidores do Tribunal de Justiça de São Paulo, Delía e Seligmann-Silva (2014) destacam alguns fatores que possibilitam a compreensão da relação saúde - trabalho - adoecimento nessa instituição judiciária, quais sejam: a ampliação das demandas para o Judiciário pelo processo de judicialização da questão social, sem o aumento do contingente dos servidores e sem uma reestruturação do Órgão para atender às transformações econômicas, políticas, sociais e culturais em curso; a descrença na instituição pública e, consequente, desvalorização da função do trabalho público na sociedade moderna; a escassez de funcionários e a lentidão burocrática na implementação de concursos para ampliação dos quadros, dentre outros fatores mais relacionados à organização do trabalho.

A depender do ramo da Justiça, além destes, outros obstáculos impõem-se ao Judiciário, dificultando o cumprimento de sua missão constitucional de dirimir conflitos e de

\footnotetext{
${ }^{3}$ Servidores públicos é o termo utilizado para designar os trabalhadores vinculados ao Estado, são pessoas que ocupam cargos públicos.
}

Barbarói, Santa Cruz do Sul, n.48, p.<106-134>,jul./dez. 2016 
aplicar as leis, diante do agravamento das contradições sociais. Trata-se, então, da tarefa da Justiça Eleitoral de mediar o jogo democrático, dada a conflitualidade existente na disputa eleitoral, na qual as classes e suas diversas frações competem pelo poder político, elemento de extrema importância para estas imporem seus interesses e seus projetos societários particulares. Diante disso, não é difícil deduzir o potencial de conflito e tensão social presente no processo político-eleitoral, os quais se particularizam, sobretudo, no trabalho dos servidores desta justiça especializada, predispondo-os ao adoecimento mental.

Assim, as mencionadas transformações que vem ocorrendo no mundo do trabalho incidem de forma destrutiva na saúde dos trabalhadores, particularmente dos servidores públicos, degradando a saúde física e mental dos mesmos e desencadeando processos de adoecimento dos quais sobressaem as doenças relacionadas ao trabalho, com destaque para o adoecimento mental. Assim, conforme aponta Mendes e Wünsch (2011, p. 466) amparadas em Dias (1994),

A reestruturação produtiva alterou substancialmente o perfil do trabalho e dos trabalhadores, assim como os determinantes da saúde-doença dos trabalhadores. Essas alterações modificaram também o perfil da morbimortalidade relacionada ao trabalho, assim como a organização e as práticas de saúde e trabalho (MENDES; WÜNSCH, 2011, p. 466).

\section{O adoecimento mental dos servidores de uma intituição judiciária: elementos para reflexão crítica}

Atualmente, o perfil de morbimortalidade dos trabalhadores, em geral, evidencia o aumento das estatísticas relacionadas aos casos de adoecimento por transtornos mentais e comportamentais e por distúrbios osteomusculares. De acordo com estimativa da Organização Mundial de Saúde 4 , "os transtornos mentais menores (quadros menos graves e mais frequentes de transtornos mentais, tais como a depressão e a ansiedade) acometem cerca de $30 \%$ dos trabalhadores ocupados, e os transtornos mentais graves, cerca de 5 a 10\%" (OMS, 2001). A propósito, importa ressaltar que a realidade dos serviços públicos, no Brasil, particularmente do Poder Judiciário segue esta tendência, com a alta incidência deste tipo de adoecimento entre seus servidores 5 .

\footnotetext{
${ }^{4}$ Relatório Mundial da Saúde: Saúde mental, nova concepção, nova esperança (OMS, 2001).

${ }^{5}$ A incidência de transtornos mentais e comportamentais nos índices de absenteísmo de órgãos e empresas foi confirmada em algumas pesquisas, inclusive em órgãos do Poder Judiciário. No Superior Tribunal de Justiça, em 2009, esses transtornos ocuparam o primeiro lugar em dias de afastamento (CARVALHO, 2010) e no Tribunal Regional do Trabalho $14^{\mathrm{a}}$ Região, com jurisdição em Rondônia e no Acre, no período de outubro/2006 a setembro/2007, ocuparam o $2^{\circ}$ lugar, ficando atrás apenas dos distúrbios osteomusculares, cujos fatores de risco envolvem também questões psicossociais (BARBOSA, SOBRAL \& CORDEIRO, 2008).
} 
Segundo Seligmann-Silva (2011, p. 33), "existe um processo social continuado que envolve os indivíduos e interage em sua complexidade psicossomática", o qual, a depender das forças políticas e sociais envolvidas, pode "favorecer ou fragilizar a saúde dos seres humanos de acordo com as situações que estes vivenciam em contextos macrossociais e situações específicas de vida e de trabalho" (IDEM, p. 33-34).

Desta forma, na área de saúde e segurança do trabalhador, alguns estudos e legislações têm contribuído para evidenciar os principais fatores de risco ao adoecimento dos trabalhadores presentes nos ambiente e processos de trabalho. A Norma Regulamentadora do Ministério do Trabalho e Emprego $\mathrm{n}^{\mathrm{o}}$ 9, por exemplo, estabelece normas e diretrizes referentes ao Programa de Prevenção de Riscos Ambientais e apresenta um mapa dos principais riscos ${ }^{6}$ ocupacionais existentes nos ambientes de trabalho, o qual engloba os riscos físicos, químicos, biológicos e ergonômicos. Ao discutir sobre o assédio moral nas relações sociais no âmbito da Administração Pública, Heloani e Barreto (2015) elencam uma série de riscos organizacionais e de estressores emocionais, interpessoais e os ligados à organização do trabalho $^{7}$, destacando que os mesmos podem desencadear sérios "danos à saúde de quem trabalha, atingindo a área psíquica, a moral e o intelecto, entre outros aspectos” (p. 147).

Dentre estes fatores estressores, os quais transformam o ambiente de trabalho em potencial risco à saúde, os referidos autores citam os seguintes: a insegurança; a competitividade; a falta de reconhecimento; a ausência de diálogo respeitoso e transparente entre os pares; o receio de ser ridicularizado e o medo daí decorrente; a falta de confiança que pode gerar informações truncadas e confusas; comunicação ambígua, próxima a "fofocas"; a avaliação individual e os conflitos nas relações de trabalho.

No âmbito das relações interpessoais, são destacados: a liderança inadequada; o exercício centralizador do poder associado à vigilância exacerbada dos trabalhadores; o predomínio de atividades confusas e contraditórias nas quais não há possibilidade de criatividade. Ampliando essa discussão, os referidos autores destacam ainda que existem as variáveis relativas ao trabalho, dentre as quais estão a sobrecarga de trabalho (física ou mental) ou sua escassez; as jornadas prolongadas que restringem outras relações sociais

\footnotetext{
${ }^{6}$ Fatores de risco são todos os aspectos da situação de trabalho que tem a propriedade e a capacidade de causar um dano e de interferir negativamente na segurança, na saúde e no bem-estar dos trabalhadores.

${ }^{7}$ Importa ressaltar que organização do trabalho é aqui entendida na perspectiva de análise do campo da saúde do trabalhador, cujos estudos centram-se na relação saúde-trabalho e buscam compreender os impactos das transformações societárias no mundo do trabalho e na saúde do trabalhador. Sua ênfase está no conceito de processo de trabalho, visualizado a partir das unidades produtivas e suas determinações para o desgaste, riscos e cenário de morbidade dos trabalhadores (MINAYO, 2013). Trata-se aqui do enfoque às condições em que o trabalho é realizado, envolvendo aspectos como cultura organizacional, tempo e ritmo de trabalho, relações de poder e controle sobre o trabalho, dentre outros elementos.
} 
significativas, como as familiares; a tarefa dissociada de sentido; o trabalho burocratizado; a supervisão com estilo autoritário; mudanças repentinas na organização; a intensificação do ritmo e a pressão por produtividade, em decorrência da incorporação de novas exigências, fatores que "associados à ausência de solidariedade e ajuda mútua, acabam por desencadear uma espiral de competitividade estimulada" (HELOANI, BARRETO, 2015, p. 148).

Diante de tantos estressores e de tantos riscos organizacionais, os mencionados autores enfatizam a necessidade de serem implementadas novas práticas no ambiente de trabalho, como uma exigência moral e ética, enfatizando que a saúde é:

resultado das condições de vida e da convivência solidária, do meio em que predominam a solidariedade e a afetividade. Quando as pessoas estão submetidas a condições de trabalho em ambientes degradados, que consideram o ser humano apenas um complemento da produção, e nos quais impera o medo, provocados por ações que infundem terror, atos de violência repetitivos causam feridas invisíveis que demoram a cicatrizar. Desse modo, pensar ações preventivas que eliminem o assédio moral no trabalho é um imperativo categórico, moral e ético. É necessário criar novas práticas e compreender que amizade e ajuda mútua possibilitam a resistência e a criatividade, potencializando a capacidade de produzir (HOLOANI; BARRETO, 2015, p. 159).

Sendo assim, a “[...] a observação [das] práticas de trabalho, bem como das relações delas decorrentes, tornam-se pertinentes em estudos que buscam compreender a relação do adoecimento com o trabalho" (MENDES, WUNSCH, 2011, p. 468); nesse bojo, foi realizada uma pesquisa qualitativa em três órgãos de uma instituição do Poder Judiciário, no Brasil, tendo como sujeitos 22 (vinte e dois) servidores, quais sejam: 09 (nove) profissionais de saúde (médicos, assistentes sociais e psicólogos), 04 (quatro) gestores de pessoal e 09 (nove) analistas e técnicos judiciários. Os dados obtidos nessa pesquisa evidenciaram a ocorrência dos seguintes adoecimentos e transtornos mentais e comportamentais entres os servidores, codificados na Classificação Internacional de Doenças (CID) como: transtorno mental e comportamental devido ao uso de álcool - dependência alcoólica (F 10.2); transtornos dos hábitos e dos impulsos - jogo patológico (F 63); transtorno mental e comportamental devido ao uso da cocaína (F 14); transtorno psicótico agudo de tipo esquizofrênico (F 23.2); psicose não orgânica não especificada ( $F$ 29); ansiedade generalizada ( $F$ 41.1); transtorno de personalidade com instabilidade emocional (F 60.3); transtorno afetivo-bipolar (F 31); estado de estresse pós-traumático (F 43.1); episódio depressivo grave sem sintomas psicóticos (F 32.2); e transtorno fóbico-ansioso (F 40).

Esses dados ratificam o que preconiza a litaratura existente no campo da saúde do trabalhador, no que se refere à alta incidência de transtornos mentais e comportamentais em termos do perfil de morbimortalidade dos trabalhadores na contemporaneidade. Os relatos de 
alguns sujeitos pesquisados são ilustrativos dessa afirmação:

[...] Nós temos sim uma demanda bastante grande pra essas questões de saúde mental, principalmente o quadro de ansiedade e depressão. Então, isso chega primeiro no campo de trabalho, com a ausência ou com a presença tumultuada, então a pessoa não se sente bem, acha que não sabe lidar com isso, com essas questões, e então encaminha a pessoa pro próprio serviço médico. Muitas vezes, a pessoa procura espontaneamente; como o serviço aqui já tem dez anos de implantado, as pessoas vão falando umas pras outras, e eles mesmos vem te procurar (Assistente Social 1; Órgão B).

[...] Pela nossa experiência [...] são bem frequentes [...] a maior parte dos afastamentos longos são relacionados ao adoecimento mental [...] no nosso setor [...] todos que chegam pra nós são de saúde mental [...]. Agora as fontes são múltiplas e questões individuais, da pessoa no trabalho quando a própria organização pode gerar um caso [...] (Psicóloga; Órgão A).

As demandas aqui elas não chegam com esses diagnósticos [...] que tá com algum problema de ordem psicossocial, mas indiretamente nós sentimos isso muito no dia a dia, quando as pessoas vem, se queixam de mal-estar, às vezes a pressão elevada ou algum outro tipo de sintoma que diretamente [...] não é uma queixa psicossocial, mas é afetável por uma situação de estresse que a pessoa enfrenta aqui no [Órgão]. [...] Acredito que ainda seja uma demanda bastante reprimida [...] (Médico; Órgão C).

[...] Conhecimento a gente tem de muitos casos de doenças mentais, várias unidades do Tribunal [...] e especificamente no período em que tive como Secretária de Gestão de Pessoas, em dois anos, eu acompanhei três casos que foram bem marcantes naquela administração, porque foram processos sérios, de servidores recém-contratados, inclusive que apresentavam uma situação normal, mas que apresentaram um adoecimento dentro do órgão em pouco tempo [...] (Secretária de Gestão de Pessoas; Órgão C).

Constata-se, ainda, que tais adoecimentos se destacam pelas graves consequências que ocasionam tanto para a vida dos servidores quanto para o trabalho na instituição, pois atingem a essência do processo de valorização do capital, ou seja, o potencial de trabalho humano e a integridade física e emocional do trabalhador, responsáveis diretos pela acumulação de riquezas. Nesse sentido, o adoecimento mental desses servidores impactou nas relações familiares dos mesmos, sob várias formas: conflitos conjugais que culminaram com o divórcio e alteração da dinâmica familiar; problemas financeiros; e no trabalho foram identificadas situações de desmotivação, isolamento social, aposentadoria por invalidez e até suicídio, conforme destacam os depoimentos dos sujeitos pesquisados, a seguir:

Todas as oportunidades possíveis imagináveis foram desperdiçadas, qual é o dirigente que vai confiar dar um cargo de confiança pra uma pessoa que tá alcoolizada? [...] então você perde a confiança das pessoas, perdas financeiras [...]. Então o impacto pra mim foi desastroso (Servidor 1; Órgão B).

Bem, no meu trabalho a gente começa a se desmotivar, [...] porque por mais que tu faças a tua parte não é reconhecido, ai tu começa a adoecer, começa a não ter motivação pra nada, principalmente pro trabalho, porque um dos focos do adoecimento é o trabalho, e a minha vida praticamente era isso, porque eu ia do hotel pro trabalho e do trabalho pro hotel [...]. Eu acabei me separando [...] então o que mais me impactou nessa história toda foi no meu casamento (Servidora 7; Órgão C). 


\begin{abstract}
Ah, são vários! Do ponto de vista institucional: desde questões reais de impactos financeiros, que a pessoa deixa de produzir [...] mesmo que ela não esteja afastada, se a produtividade dela não está ocorrendo, se o relacionamento também, isso vai impactar as equipes, de forma que você pode ter problemas ali de relacionamento [...]. Tem uns casos [que vão] chegar a gerar uma aposentadoria [...] a gente tem um caso de usuário de crack, caso grave, e já foi tentado tudo [...] e ele vai se aposentar, [...] é triste! (Psicóloga; Órgão A).

[...] Houve um caso de uma pessoa do Tribunal que se suicidou, saiu até no Jornal Nacional (Gestor de Pessoal, chefe de setor; Órgão B).
\end{abstract}

A situação de adoecimento dos trabalhadores acima mencionada pode ser compreendida se tomarmos como referencia o processo saúde-doença analisado como um fenômeno social e histórico (LAURELL, 1982), conforme preconizam as Reformas Sanitária e Psiquiátrica, a partir da década de 1980. Sendo assim, tem-se que a saúde é resultado das condições de vida e de trabalho dos sujeitos sociais, logo: vários riscos, isoladamente ou em interação, podem contribuir para o surgimento de problemas de saúde em geral e, notadamente, de saúde mental, os quais devem ser analisados em sua totalidade e na relação com o contex to social no qual vive o trabalhador.

Dessa forma, quando os sujeitos pesquisados foram questionados sobre os fatores que contribuíram para os processos de adoecimento identificados, tanto aqueles relacionados ao trabalho quanto aos externos a este, foram sinalizados: no que tange aos primeiros, evidenciou-se os conflitos nas relações interpessoais no ambiente laboral e a falta de condições de trabalho, apontados por 05 (cinco), dos 09 (nove) servidores entrevistados e por profissionais de saúde e gestores.

No que tange aos fatores externos ao trabalho, experiências frustrantes de vida (falência de empresa), problemas urbanos (violência, trânsito precário), violência doméstica, conflitos familiares, ou mesmo eventos comuns da vida que geram tristeza e angústia (morte de um familiar, divórcio) compuseram os processos que impactaram a saúde mental dos servidores dos referidos órgãos.

Com relação aos elementos relacionados ao trabalho, identificou-se que: a postura rígida e autoritária das chefias, especialmente na cobrança exagerada por produtividade, por vezes caracterizada como assédio moral; os critérios patrimonialistas na concessão de benefícios no órgão; a competitividade entre os servidores pela ocupação das funções comissionadas; assim como a falta de condições de trabalho apropriadas foram os principais fatores causadores de insatisfação e desmotivação dos servidores e, consequentemente, das situações de adoecimento apresentadas pelos mesmos. Neste sentido, os depoimentos abaixo evidenciam o processo de adoecimento, sendo bastante ilustrativos: 
É o trabalho sim, e o meu quadro de depressão, que era leve, ele foi se acentuando; então, eu procurava fuga no álcool, no jogo, mas, de 2009 pra cá, eu conheci a cocaína [...] eu estava fugindo na verdade [...]. No [Órgão], houve um cartório pelo qual eu passei, [...] houve duas mudanças de chefia, a terceira chefe que entrou recebeu ordens da Diretora Geral pra fazer uma espécie de limpeza no cartório, só que ela exagerou na dose, começou a assediar moralmente praticamente todos os servidores, sofria pressões diárias lá, assim, quanto à cobrança do trabalho, ela falou que estava tudo errado, tudo mal feito, que os processos estavam atrasados, que deixava a desejar; ela chegou com uma postura super autoritária, até aos gritos [...]; o que acabou me abalando psicologicamente [...] fiquei com um quadro de depressão que culminou com licenças médicas periódicas [...]. Saí do céu pro inferno [...] em questão de meses (Servidor 2; Órgão B).

[...] Eu comecei a trabalhar na seção [...]; lá é um setor completamente insalubre, [...] comecei a sentir problemas de alergia aos produtos químicos, [...] vinha passando muito mal, adoecendo [...]. Um médico da equipe [...] disse que se eu conseguisse um laudo falando que, realmente, tinha alergia aos produtos químicos de lá, ele me daria a readaptação [...] foi o que eu fiz e ele negou [...] Eu fui obrigada a ficar lá, [...] até que eu vim questionar porque tinha uma outra colega do mesmo cargo que ficou aqui, porque ela tem privilégios, tem amizades, tem influências, ficou fora da lotação, por uns tempos? [...] Eu tive que entrar na justiça contra o [Órgão]. [...] Com isso, não me obrigaram mais a voltar pro setor, mas fiquei no setor que era ligado a ele; lá sofri muita perseguição [...], eu era muito intimidada! [...]. Fiquei muito revoltada com isso. [...] De lá pra cá, me sinto muito mal aqui [...] Eu adoeci aqui por isso, tenho muito rancor! (Servidor 5; Órgão A).

Quando eu passei [no concurso] foi uma alegria! [...] tava com todo gás querendo fazer o melhor de mim, em trabalhar e produzir, [...] fui sozinha! [...] E enfrentei, peguei um avião, depois um barco, não sabia nem o que me esperava lá, cheguei lá [...] fui bem recebida pelos servidores, mas [...] fui com um pouco de medo, desde e o treinamento, as próprias pessoas da Corregedoria me chamaram pra me avisar que eu poderia enfrentar uma barra lá, porque a cedida da prefeitura que já estava lá há muito tempo como chefe de cartório [...] achava que a gente ia [...] tomar o lugar dela [...]. Então, o Tribunal obrigou a juíza a me colocar na chefia, porque é uma determinação. [...] A [servidora requisitada] começou a fazer minha cabeça pra juíza [...] [que] começou a implicar comigo, me tratar mal [...] porque [...] pra ela [a requisitada] ser chefe do cartório [...] ela ganha mais, imagina pra quem ganha um salário mínimo, lá na prefeitura, ganhar mil reais a mais!? [...]. Eu já estava fragilizada, sozinha, [...] é uma cidade que dava certa hora fechava tudo, tu ficava no hotel e não tinha nada pra fazer, e eu tinha acabado de perder meu avô também, e eu nunca tinha passado por isso de sair daqui também, da minha casa. Enfim, já era difícil minha vida lá, e com esses problemas se tornou muito mais difícil [...] (Servidor 9; Órgão C).

Os depoimentos acima revelam que as relações de trabalho são fortemente atingidas por problemas de relacionamento, decorrentes de posturas autoritárias das chefias, tratamento diferenciado por relações patrimonialistas, perseguição, dentre outros, os quais contribuíram para a desestabilização emocional de certos servidores, desencadeando ou agravando o adoecimento e afastamento prolongado do trabalho. Ressalta-se que práticas desta natureza "não são exclusivamente resultado da ação de sujeitos perversos" ou mesmo de determinado perfil psicológico, "ainda que os assediadores não devam ser isentos da responsabilidade que lhes cabe" (SOBOL, HELOANI, 2008, apud CHAPADEIRO, 2015, p. 165). No Brasil, o conceito de assédio moral refere-se a uma 
[...] conduta abusiva, intencional, frequente e repetida, que ocorre no ambiente de trabalho e que visa diminuir, humilhar, vexar, constranger, desqualificar e demolir psiquicamente um indivíduo ou grupo, degradando as suas condições de trabalho, atingindo a sua dignidade e colocando em risco a sua integridade pessoal e profissional (HIRIGOYEN, 2000, p. 37, Apud HELOANI; BARRETO, 2015, p. 146).

Por oportuno, cabe se referir às análises de Sobol e Heloani (2008, apud CHAPADIERO, 2015, p. 166) acerca do assédio moral, o qual, para eles, é antes de tudo, o resultado

\footnotetext{
[...] das relações estabelecidas entre os trabalhadores determinado por uma organização do processo de trabalho específica, inserida em uma lógica macroeconômica capitalista permeada por relações de poder e que invade cada vez mais a Administração Pública (HIRIGOYEN, 2000, p. 37, Apud HELOANI; BARRETO, 2015, p. 166).
}

Nesse sentido, ainda que as denúncias no âmbito do serviço público sejam raras, além das consequências físicas e psíquicas impostas às vítimas, a concretude do assédio moral neste espaço prejudica sobremaneira o trabalho exercido pelos servidores e, consequentemente, o cumprimento das ações do Estado, uma vez que, no mínimo, o servidor assediado será afastado de suas funções para gozo de licença médica, o que poderá incidir na queda da produtividade, desmotivação, problemas de concentração e falhas no desempenho (CHAPADEIRO, 2015).

Ademais, conforme afirma o referido autor (idem), como o vínculo jurídico com a administração pública será mantido e esta não suprirá a ausência deste servidor, uma vez que não poderá realizar concurso público para substituí-lo, a sobrecarga de trabalho em outros servidores poderá repercutir também no adoecimento destes, visto que alguém terá que assegurar a produtividade do servidor afastado; logo, o assédio moral "caminha na contramão do princípio da eficiência, assegurado constitucionalmente" (CHAPADEIRO, 2015, p. 165).

No bojo desta discussão, importa registrar, ainda, que a análise do assédio moral impõe a consideração das relações de poder que perpassam as estruturas estatais, o que remete à necessidade de considerar a própria formação do Estado brasileiro, notadamente, a sua herança colonialista e a cultura pouco democrática das transformações econômicas, políticas e sociais ocorridas ao longo da história do país, determinadas, em essência, pelo pacto entre o Estado e as elites governantes nacionais associadas ao capital internacional.

Dessa forma, forjaram-se as características autocráticas do Estado brasileiro, marca histórica da formação político-econômica do país, delineada pela pouca influência da sociedade civil nos processos de transformação nacional, situação que se alterou, em parte na 
década de 1980, mas que determinou a constituição de uma nação "a partir do Estado e não das massas" e acabou por definir a constituição de instituições cujas estruturas são permeadas por relações de poder marcadas pelo autoritarismo, a título de exemplo as instituições judiciárias (COUTINHO, 2008. Grifos do autor).

Pelo exposto, constata-se que as relações de poder atravessam as relações sociais e não podem ser dissociadas da funcionalidade econômica que este instrumento assume para manter as condições necessárias e elementares à produção material e à dominação de classe, inclusive nas estruturas estatais. Como resultado, tais traços influenciam a condução das políticas de gestão das diversas instituições que compõem o aparelho estatal e os fatores que contribuem para o adoecimento dos servidores públicos, como por exemplo: a cobrança exagerada por produtividade, também enfocada pelos servidores. Segundo Ribeiro (2009), na contemporaneidade, existe uma pressão maior por resultados no serviço público, o que reflete um processo de incorporação dos padrões privados e produtivistas e dos valores burgueses neste setor, ocasionando a deterioração das relações de trabalho aí existentes.

Sabe-se que essas exigências de produtividade estão atreladas ao processo de Reforma do aparelho do Estado, sob o discurso da modernização das estruturas estatais, com vistas a torná-las mais eficientes, por meio da implantação de novas práticas de gestão que modificaram os processos de trabalho e as relações entre as pessoas, tanto entre seus próprios servidores, quanto destes com o público atendido, visando ao aperfeiçoamento da administração burocrática existente, o que tem gerado sérias consequências para a vida pessoal, social e profissional dos mesmos.

Entretanto, esta reforma iniciada no bojo da reestruturação produtiva e do avanço da política neoliberal no serviço público apresenta um caráter extremamente contraditório, uma vez que, ao mesmo tempo em que impõe novas exigências de eficiência às instituições e a seus trabalhadores, restringe as possibilidades de resposta às mesmas, dada a lógica fiscal que a permeia, cujas diretrizes definem a contenção dos gastos públicos como uma das principais medidas, o que reverbera na precarização neste setor.

Desta feita, tem-se um verdadeiro choque de gestão, pois os padrões de eficiência e produtividade da administração gerencial impactam nos servidores devido à estrutura rígida, burocrática e patrimonialista dos Poderes de Estado, a exemplo do Judiciário, tendo como agravante a falta de condições de trabalho delineadas pelo processo de precarização assinalado acima. Como resultado, este "choque de gestão" intensifica o trabalho estranhado e causa inúmeros danos à saúde dos trabalhadores (ALVES, PALMELA, 2011, p. 50-51), criando condições favoráveis às posturas de assédio moral, conforme identificado na pesquisa. 
Ressalta-se que diversos depoimentos de profissionais de saúde e dos gestores entrevistados corroboram os relatos dos servidores no que tange à influência danosa à saúde mental ocasionada pelas condições laborais precárias existentes especialmente nas unidades estratégias das instâncias judiciárias, pelo avanço de padrões produtivistas sobre os processos e relações de trabalho nesta Justiça especializada e pela estrutura rígida e burocrática aí existente, refletida em um trabalho extremamente burocratizado e repetitivo, pouco incentivador da disposição criativa do trabalhador e de seu potencial intelectual, e pelos critérios políticos utilizados para a concessão de benefícios. Os depoimentos abaixo são ilustrativos a esse respeito:

No serviço público, nós temos um fator [...] que é: aparentemente nós não teríamos a questão do lucro, mas nós temos uma exigência de cumprimento de metas, uma pressão de atingir o maior número de processos durante o ano. Por outro lado, você tem que mostrar que o processo de trabalho não é perguntado, não é um processo compartilhado, ele vem de cima pra baixo [...]. Tem pessoas que tem esse ritmo diferente, não conseguem produzir bem em ritmo acelerado, então umas das grandes questões que se colocam é: como o serviço público gerencia seu processo de trabalho? [...] A falta de diretrizes, a falta de comunicação, uma exigência que está sendo incorporada, no público que vem do privado, [...] as próprias avaliações do desempenho vem de encontro a isso. Não que o trabalho não precise ser monitorado, avaliado. [...] E recai numa outra questão, há uma exigência grande para com o servidor, só que as condições pra que esse trabalho seja executado não são observadas. [...] Muitas das seções ou dos próprios cartórios não têm espaço adequado para o trabalho, com iluminação suficiente, com um mobiliário suficiente, porque não se tem só uma manifestação mental, há outras manifestações por doença mesmo, como também os distúrbios osteomusculares, que acabam traduzindo num sofrimento físico [...] um adoecimento psíquico também, porque é a questão da dor. Como é que você vai passar por esse processo, voltando ao mesmo espaço físico? (Assistente social 1; Órgão B).

[...] A questão principal é a financeira, no sentido de que quando se muda a gestão, muda todo o escalão e muitas pessoas que já incorporaram o DAS, no salário do mês, vão ficar sem aquele salário, e isso acabada causando um estresse muito grande nas pessoas que estão em vias de perder uma função. [...] Isso aí, na conjuntura atual, se torna ainda mais grave porque, hoje, o salário do servidor do judiciário está muito achatado ${ }^{8}$, então depende muito do cargo comissionado! [...] Coisa que até alguns anos atrás, talvez não estivesse tanto pro servidor, porque o salário base [...] era um valor razoável [...] até acima da média do mercado, então a pessoa conseguia sobreviver com aquele salário sem DAS?! Hoje, a maioria das pessoas que estão com DAS, se ficar sem, vai passar um período de dificuldade. E isso causa, obviamente, um estresse emocional muito grande nas pessoas, e por conta disso adoecem muito mais (Médico; Órgão C).

Tem muito da instituição. [...] o judiciário, dos poderes é o mais atrasado de gestão, onde ainda prevalece muito reformas não técnicas de gestão, de eleição de quem vai ocupar cargos, e isso tudo vai frustrando as pessoas. Chefes que não são adequados pra lidar com pessoas, acham que chefiar é só tecnicamente, e isso vai acumulando [...] insatisfações e acaba eclodindo os casos [...]. A gente tem essa questão de estar em uma instituição onde concurso é muito exigente, e as pessoas que entram são

\footnotetext{
${ }^{8}$ A tabela remuneratória do servidor público dos Tribunais do Poder Judiciário federal aponta que o vencimento básico do cargo de analista judiciário situa-se entre $\mathrm{R} \$ 4.633,67$ e $\mathrm{R} \$ 6.957,41$ e o do cargo de técnico judiciário situa-se entre R $\$ 2.824,17$ e $\mathrm{R} \$ 4.240,47$. Fonte:http://www.tre-sp.jus.br/transparencia/relatorios-cnj/recursoshumanos-e-remuneracao/estrutura-remuneratoria-cargos-efetivos; acesso em 01 set 2015.
}

Barbarói, Santa Cruz do Sul, n.48, p.<106-134>,jul./dez. 2016 
muito qualificadas; o Tribunal [...] é um tribunal administrativo, então são poucos os lugares que as pessoas podem ser estimuladas intelectualmente (Psicóloga; Órgão A).

Importa destacar ainda, com base nos depoimentos dos sujeitos pesquisados, que o fator econômico relacionado ao adicional financeiro garantido pela função comissionada, no Tribunal, é um elemento potencializador de conflitos, sobretudo no contexto atual marcado pelo avanço da política neoliberal que amplia o poder do mercado e determina o avanço da racionalidade burguesa para outras esferas da vida social, consubstanciada na lógica fiscal de contenção de gastos públicos, de viés economicista, expressa, dentre outros elementos, no arrocho salarial que atinge o servidor público, embora disponham de algumas condições que os diferenciam da massa trabalhadora em geral, no que tange ao seu maior padrão remuneratório que amplia seu potencial de consumo e acesso a determinados bens e serviços.

Como resultado desse processo, produz-se um quadro de insatisfação geral, tanto dos servidores públicos que veem solapados os seus direitos, os seus anseios de condições dignas de vida, de status social, quanto da própria população que procura os serviços públicos, a qual muitas vezes é vítima da degradação da qualidade dos serviços a ela dirigidos e da violência institucionalizada, em decorrência do avanço dos interesses privados nessa esfera, na qual deveria imperar as necessidades sociais e universalidade de direitos (IDEM).

Isso porque, diante da complexificação da estrutura social na atualidade, refletida na polarização entre seus dois polos (trabalhadores de base e detentores do capital) devido ao aumento das desigualdades sociais (POCHMANN, 2012), os servidores públicos, enquanto classe média ${ }^{9}$, constatam a intensificação das marcas de sua condição de proletariedade, em que pese a dificuldade de se reconhecerem como trabalhadores assalariados do Estado inseridos nas relações de classe da sociedade capitalista (RIBEIRO, 2009) ${ }^{10}$.

$\mathrm{Na}$ realidade, a análise dos fatores que contribuíram para o adoecimento dos mencionados servidores revela que está em curso um processo de deterioração das relações

\footnotetext{
${ }^{9}$ Segundo o Dicionário do pensamento marxista (BOTTOMORE, 2012), em Marx, este termo foi usado para designar a classe ou camada social que está entre a burguesia e o operariado. A classe média é formada também por profissionais de nível médio e superior (médicos, administradores, engenheiros, professores, técnicos, etc.), cuja força de trabalho se baseia na qualificação e formação, a qual, embora não transforme materiais em bens econômicos (de uso e de troca), agrega valor ao capital, por seus conhecimentos científicos e tecnológicos (BRAVERMAN, 1987). Atualmente, esta classe assume feições particulares, pois, diferentemente da antiga classe média, corresponde "cada vez mais à definição de uma classe trabalhadora", na medida em que "não possui qualquer independência econômica ou ocupacional", necessitando "renovar seus trabalhos para o capital incessantemente a fim de subsistir" (IDEM, p. 341).

${ }^{10}$ Segundo Alves e Palmela (2011), no Poder Judiciário, o caráter fetichizado das determinações sociais assume uma significação ímpar, pois os servidores apresentam-se como "serviçais do fetiche da Justiça [considerada] alma do Estado político do capital" (p.44), "isto é, servos de uma das personas da dominação do capital mais impregnado de fetichismo: o Estado político" (p. 43). Dessa forma, a condição de trabalhador aparece ocultada na consciência de tais sujeitos pela visão do Estado como ente orgânico acima das classes sociais.
} 
sociais da qual o sofrimento decorre (WERLANG, MENDES, 2013, p. 754), como um sofrimento social ${ }^{11}$, confirmando os rebatimentos das contradições sociais da sociedade capitalista contemporânea na produção do sofrimento mental, o que parece explicar, de certa forma, a reação de estranhamento de um dos profissionais de saúde pesquisados, ao comentar que os conflitos nas relações de trabalho eram os principais fatores que contribuíam para o adoecimento dos servidores no Tribunal pesquisado, enfatizando que isso não é uma doença. O relato abaixo é elucidativo, neste aspecto:

Mas eu diria que dentro do tribunal o que eu vejo, assim, é o conflito interpessoal que vira entre aspas uma doença, porque eu nem posso dizer que isso é doença! Eu já falei assim: gente, isso não é doença, isso aí é um problema de relação de fulano com sicrano, tem que resolver lá de outra maneira, não tem que virar tudo doença! (Médica Psiquiatra; Órgão A).

\section{Considerações finais}

As premissas do movimento sanitarista da década de 1980 afirmam que a saúde é uma totalidade complexa, constituída de múltiplas determinações, aí considerada a perspectiva de classe no que se refere ao acesso a bens e serviços, o que fora ratificado pelos resultados da pesquisa ora apresentada, que evidenciaram os rebatimentos das contradições sociais da sociedade capitalista contemporânea na produção do sofrimento mental dos servidores públicos dos Tribunais estudados.

Os quadros de adoecimento dos referidos servidores, como visto, indicam uma relação com a forma de gestão do trabalho adotada nestes órgãos, as quais, por sua vez, são determinadas pelas mudanças implementadas no serviço público brasileiro a partir do processo de Reforma do Estado em curso desde os anos de 1990 e no Judiciário remonta aos anos 2000, cujas repercussões envolvem um processo de precarização crescente das condições de trabalho e de vida de tais servidores, predispondo-os a adoecimentos mentais, prejudicando a saúde dos mesmos.

Tal situação pode ser, ainda, explicada pelo forte tensionamento inerente às disputas políticas acirradas entre os projetos societários divergentes pela conquista do poder político,

\footnotetext{
${ }^{11}$ Werlang e Mendes (2013) apresentam o conceito de sofrimento social para explicar os sofrimentos que tem uma origem social e que aparecem como uma "espécie de resposta psicológica, subjetiva à dor" (idem, p. 744), estando presentes "nos sentimentos de isolamento social, de perda, de sentimentos aliados à depressão, ansiedade, culpa, humilhação e estresse" (idem, p. 744). Para essas autoras (2013), no sofrimento social ocorre a interseção entre indivíduo e sociedade e entre o social e o psíquico, o que não é apreendido de forma imediata, pois é saturado de mediações. Assim, o vínculo existente entre as estruturas econômicas e sociais e os comportamentos individuais são revelados na "(...) violência estrutural exercida pelos mercados financeiros, sob a forma de desemprego, de precarização, [os quais] tem sua contrapartida, em maior ou menor prazo, sob a forma de suicídios, delinquência, crimes, drogas, de pequenas ou grandes violências cotidianas" (BOURDIEU, 1998, p. 56, apud WERLANG, MENDES, 2013, p 748).
} 
dimensão essencial da luta pela hegemonia nesta sociedade, o que se reflete em intensa pressão sobre os servidores desses Tribunais. Desta feita, o avanço do ideário neoliberal sobre o serviço público aparece consubstanciado em práticas de gestão baseadas nas metas de produtividade, na intensa competitividade entre os trabalhadores, nas gestões marcadamente autoritárias, na exigência de polivalência aos servidores, dentre outras situações, confirmando que a lógica produtivista, antes restrita ao âmbito da produção (empresas, fábricas), avança pelos serviços públicos, cuja natureza e finalidade são bastante diversas, atingindo sobremaneira os servidores públicos, notadamente, a saúde deste trabalhador.

Ademais, importa ressaltar que tal estratégia de gestão é incorporada a instituições públicas cujas estruturas são legados das marcas históricas que delinearam a formação do Estado brasileiro, pouco permeável à uma cultura democrática, favorecedora da discussão sobre o processo de trabalho e da autonomia dos servidores. Com efeito, tem-se, então, um verdadeiro choque entre a herança autoritária, patrimonialista e burocrática do Estado e a nova ênfase gerencial das políticas estratégicas de gestão de pessoas implantadas nos órgãos públicos.

Diante desse contexto, destaca-se que a compreensão das questões que tangenciam os problemas na área da saúde mental em face do aumento das estatísticas de adoecimento mental, em nível mundial, não pode prescindir da análise das mediações sociais componentes desse processo, sob pena de se criar políticas e estratégias de enfrentamento incoerentes com as necessidades sociais que se apresentam, o que tem profundas implicações ético-políticas, uma vez que a forma de se conceber o fenômeno saúde-doença dos trabalhadores influencia o processo de intervenção como um todo.

Sendo assim, é necessário ampliar o debate sobre os processos saúde-doença dos servidores públicos, em especial porque, como visto, os impactos das situações de adoecimento mental afetam sobremaneira não somente a vida de tais sujeitos e de suas famílias, mas também a missão institucional dos órgãos, constituindo-se em verdadeiros desafios para as equipes de saúde, gestores e para a administração pública em geral.

Entende-se ser, igualmente, necessário "refiliar os indivíduos por meio dos tradicionais suportes da propriedade social ou por novos suportes sociais" (CASTEL, 1998, p. 536, apud WERLANG, MENDES, 2013), o que envolve o estímulo a um processo de construção cotidiana de novas estratégias que afirmem os direitos sociais e as políticas sociais universais, capazes de reforçar laços e solidariedades ameaçadas e de reinventar o sentido do público (ALMEIDA, 2004), reverberando na oferta de serviços públicos de qualidade à população, o que perpassa pela garantia de condições de vida, de trabalho e de saúde dignas 
aos servidores públicos. Isso porque a atenção psicossocial deve ser entendida como algo que engloba reabilitação, cidadania e política (LEME, 2013).

Sob essa ótica, cabe enfatizar que a garantia de direitos relacionados a melhores condições de trabalho e de saúde tem como um importante desafio contribuir para a formação da consciência de classe do servidor público, sobretudo, devido à dificuldade de tais sujeitos reconhecerem sua condição de proletariedade (ALVES, 2011), enquanto trabalhadores assalariados do Estado inseridos nas relações de classe da sociedade capitalista (RIBEIRO, 2009), processo este essencial para a conquista dos mencionados direitos, a qual depende da luta política e da capacidade de organização da classe trabalhadora.

Este é um campo privilegiado para a criação de estratégias que favoreçam a mobilização e a participação social dos trabalhadores na luta por direitos sociais, para a pesquisa e a promoção da saúde dos servidores.

\title{
NEW FORMS OF MANAGEMENT OF WORKFORCE OF PUBLIC SERVICE BRAZILIAN AND REPERCUSSIONS FOR MENTAL ILLNESS: A STUDY ON THE SERVERS OF A JUDICIAL INSTITUTION
}

\begin{abstract}
This article is a result of an analysis carried out on the data obtained by carrying out an empirical research carried out with 22 (twenty two) servants of a judicial institution, problematized in the light of critical social theory. It aims to analyze the new forms of workforce management adopted by the Brazilian public service, starting in the 1990s, and its repercussions for the mental illness of such workers. It is concluded from this study that these new forms of management based on the so-called flexible accumulation model, guided by neoliberal ideas, advance in the public service, consolidating the privatist and productivist logic, previously restricted to the business sphere, with impacts on the increase The process of precariousness that affects both personal and professional living conditions and the health of servants and the fulfillment of the mission of public institutions. This ratifies, therefore, the need for collective construction of new strategies of struggle aimed at the realization of rights through universal public social policies, aiming to rescue the sense of public service in Brazilian society.
\end{abstract}

Keywords: Management Workforce. Neoliberalism. Mental illness. 


\title{
NUEVAS FORMAS DE GESTIÓN DE PERSONAL DE SERVICIO PÚBLICO DE BRASIL Y REPERCUSIONES PARA ENFERMEDAD MENTAL: UN ESTUDIO SOBRE LOS SERVIDORES DE UNA INSTITUCIÓN JUDICIAL
}

\begin{abstract}
Resumen
Este artículo es el resultado del análisis efectuado sobre los datos obtenidos con la realización de una investigación empírica realizada junto a 22 (veintidós) servidores de una institución judicial, problematizada a la luz de la teoría social crítica. Tiene como objetivo analizar las nuevas formas de gestión de la fuerza de trabajo adoptadas por el servicio público brasileño, a partir de los años 1990, y sus repercusiones para el enfermo mental de tales trabajadores. Se concluye, a partir de ese estudio, que esas nuevas formas de gestión basadas en el llamado modelo de acumulación flexible, orientadas por las ideas neoliberales, avanzan en el servicio público, consolidando la lógica privatista y productivista, antes restringida al ámbito empresarial, con impactos en el aumento Del proceso de precarización que alcanza tanto las condiciones de vida personal / profesional y la salud de los servidores como el cumplimiento de la misión de las instituciones públicas. Se ratifica, con ello, la necesidad de construcción colectiva de nuevas estrategias de lucha dirigidas a la concreción de derechos a través de políticas sociales públicas universales, con el objetivo de rescatar el sentido del servicio público en la sociedad brasileña.
\end{abstract}

Palabras clave: Gestión de la fuerza laboral. El neoliberalismo. La enfermedad mental.

\section{Referências}

ALMEIDA, A. W. B. Solidariedades ameaçadas e a redefinição do serviço público. In: NEVES, R.H.N. et. Al (org). A reinvenção do social: poder local e a política de assistência social em Belém. Belém: Paka-Tatu, 2004.

ALVES, G. Trabalho e subjetividade: o espírito do toyotismo na era do capitalismo manipulatório. São Paulo: Boitempo, 2011.

.; PALMELA, T. Trabalhadores públicos e sindicalismo no Brasil: o caso dos trabalhadores públicos do Judiciário Brasileiro. Revista Pegada, v. 12, n.1, jun. 2011. Disponível em: http://revista.fct.unesp.br/index.php/pegada/article/view/912/942. Acesso em: 15 fev. 2014.

ANDERSON, P. Balanço do neoliberalismo. In.: SADER, E. \& GENTILI, P. (org.). Pósneoliberalismo. As políticas sociais e o Estado democrático. $6^{\text {a }}$ ed. Rio de Janeiro: Paz e Terra, 1995.

ANTUNES, Ricardo. Adeus ao trabalho?. São Paulo: Cortez, 2006.

Os Sentidos do Trabalho: Ensaios sobre a afirmação e a negação do trabalho. São Paulo: Boitempo editorial, 2009.

BARBOSA, I. L. V; SOBRAL, J. E. G; CORDEIRO, T. G. Absenteísmo por Transtornos Psíquicos no Tribunal Regional do Trabalho - 14 ${ }^{\text {a }}$ Região. Porto Velho, 2008. [Online] Disponível 
http://www.trt14.gov.br/acordao/producao_intelectual/Absenteismoportranstornos.pdf, acesso em 24 de março de 2012.

BEHRING, E. R. Brasil em contra-reforma: desestruturação do Estado e perda de direitos. 2. ed. São Paulo: Cortez, 2008.

BOTTOMORE, T. Dicionário do pensamento marxista. 2. ed. Rio de Janeiro: Zahar, 2012.

BRASIL. Ministério da Administração e Reforma do Estado (MARE). Plano Diretor da Reforma do Aparelho de Estado. Brasília, 1995.

BRAVERMAN, H. Trabalho e capitalismo monopolista. Ed. Guanabara, 3 ed., Rio de Janeiro, 1987.

CARVAlHO, M. V. L. de. Perfil do absenteísmo no Superior Tribunal de Justiça: análise do ano de 2009. Faculdade de Ciências da Saúde - Universidade de Brasília. Brasília, 2010.

[Online]. Disponível em http://bdjur.stj.gov.br/xmlui/bitstream/handle/2011/33659/Perfil_Absente\%C3\%ADsmo_M\% C3\%A1rcia\%20Valesca.pdf?sequence=1, acesso em 23 de março de 2012.

CFESS. Parâmetros para a atuação dos assistentes sociais na politica de saúde. Brasília: CFESS, 2010.

CHAPADEIRO, B. Relato de caso de assédio moral num Hospital Público de São Paulo: entre o (des)serviço e a (in)justiça. In: GEDIEL, J. A. P (org.). Estado, poder e assédio: relações de trabalho na dministração pública. Curitiba: Kairós edições, 2015.

CHESNAIS, F. A mundialização do capital. São Paulo: Xamã, 1996.

COUTINHO, C. N. A época neoliberal: revolução passiva ou contra-reforma? In: Contra a corrente: ensaios sobre democracia e socialismo. São Paulo, Cortez, 2008.

DAIN, S.; SOARES, L. T. Reforma do Estado e políticas públicas: relações intergovernamentais e descentralização desde 1988. In: OLIVEIRA, M. A. (org.). Reforma do Estado e Políticas de Emprego no Brasil. Campinas: UNICAMP, 1988, p. 31-72.

DAL ROSSO. Mais trabalho! A intensificação do labor na sociedade contemporânea. São Paulo: Boitempo, 2008.

DELÍA, A. A.; SELIGMANN-SILVA, E. Trabalho e saúde no Tribunal de Justiça de São Paulo. Repercussões na vida de seus trabalhadores. Relatório final da pesquisa. São Paulo: AASPTJ-SP, AFFOCOS, ASSOJUBS, ASSOJURIS, 2014.

FARIA, J. E. O Poder Judiciário nos universos jurídico e social: esboço para uma discussão de política judicial comparada. Serviço Social e Sociedade, n. 67, São Paulo: Cortez, 2001.

FREIRE, L. M. B. O Serviço Social na Reestruturação Produtiva - Espaços, programas, direções e processos do trabalho profissional. 3 ed. São Paulo: Cortez, 2010. 
GUERRA, Y. O conhecimento crítico na reconstrução das demandas profissionais contemporâneas. In: BAPTISTA, M. V.; BATTINI, O. (org). A prática profissional do assistente social: teoria, ação, construção do conhecimento. Vol. 1. São Paulo: Veras Editora, 2014.

HARVEY, D. A condição pós-moderna. São Paulo: Loyola, 1995.

HELOANI, R; BARRETO, M. Assédio moral nas relações sociais no âmbito das instituições públicas. In: GEDIEL, J. A. P (org.). Estado, poder e assédio: relações de trabalho na dministração pública. Curitiba: Kairós edições, 2015.

IAMAMOTO, M. V. A questão social no capitalismo. Revista Temporalis, ABEPSS, Ano 2, n. 3, jan./jul. 2001, Brasília: Grafline, 2001.

Trabalho e indivíduo social: um estudo sobre a condição operária na agroindústria canavieira paulista. 4 ed. São Paulo: Cortez, 2011.

LAURELL, A. C. A saúde como processo social. Revista Latinoamericana de Salud, México, 2, 1982, pp. 7-25. Trad. E. D. Nunes. Disponível em: http://fopspr.files.wordpress.com/2009/01/saudedoenca.pdf. Acesso em: Acesso em: 15 jan. 2014.

LEME, C. C. C. P. O assistente social na saúde mental, um trabalho diferenciado, uma prática indispensável. In. NICÁCIO, E. M.; BISNETO, J. A. A prática do assistente social na saúde mental. Rio de Janeiro: Editora UFRJ, 2013.

LOJKINE, J. A revolução informacional. São Paulo, Cortez, 1995.

MANDEL, E. A Crise do Capital: os fatos e sua interpretação marxista. São Paulo: Ed. Ensaios, 1990.

MARX, K. O Capital. Vol. I, Parte III. Ed. Difel. São Paulo: Cap. V, 1982.

Capítulo Inédito D'O capital: resultados do processo de produção imediato. Publicações escorpião, dezembro de 1975.

O Capital: Crítica da economia política. Livro Primeiro, Tomo 1, v. 1. São Paulo: Nova Cultural, 1988.

Trabalho alienado e superação positiva da auto-alienação humana. (Manuscritos Econômicos e Filosóficos 1844). In: FERNANDES, F. (Org.). Marx e Engels. História. São Paulo: Ática, 1989 (Coleção Grandes Cientistas Sociais).

(Os Economistas).

O Capital. Livro Primeiro, t. 1 e 2, v. I e II, São Paulo: Nova Cultural, 1996.

MINAYO, M. C. S. Desafio do conhecimento: pesquisa qualitativa em saúde.13 ed. São Paulo: Hucitec, 2013. 
MENDES, J. M. R.; WÜNSCH, D. S. Serviço Social e a saúde do trabalhador: uma dispersa demanda. Serviço Social e Sociedade, São Paulo, Cortez, n. 107, jul./set. 2011.

OMS. Relatório sobre a saúde no mundo 2001. Saúde mental: nova concepção, nova esperança. OMS, 2001.

POCHMANN, M. Nova classe média?: o trabalho na base da pirâmide social brasileira. São Paulo: Boitempo, 2012.

RIBEIRO, H. P. Os operários do Direito. 2 vol. Florianópolis: Lagoa Editora, 2009.

SELIGMANN-SILVA, E. S. Trabalho e desgaste mental: o direito de ser dono de si mesmo. São Paulo: Cortez, 2011.

SENA; G. A.; SILVA, E. A.; LUQUINI, R. A. A reforma do Poder Judiciário no Brasil: uma análise a partir do modelo gerencial. Revista de Ciências da Administração, Santa Catarina, Universidade Federal de Santa Catarina, 2012. v. 14, n. 33, p. 68-78

SOUZA, M. F. de. Condições, determinações e particularidades do processo de trabalho do assistente social nos órgãos do Poder Judiciário sediados em Brasília. 2004. Dissertação (Mestrado) - Universidade de Brasília. Departamento de Serviço Social, Brasília, DF, $2004 . \quad$ Disponível em: <http://www.scielo.br/scielo.php?script=sci_nlinks\&ref=000104\&pid=S14144980201100020001300016\&lng=en>. Acesso em: 20 nov. 2012.

UGÁ, V. D. A categoria "pobreza" nas formulações de política social no Banco Mundial. Revista de Sociologia Política, Curitiba, n. 23, p. 55-62, nov. 2004.

WERLANG, R.; MENDES, J. M. R. Sofrimento Social. Serviço Social e Sociedade, São Paulo: Cortez, n. 116, out./dez. 2013, p. 743-768.

ZANIN, F.; KÜNZLE, L. A.; BARRETO, M.; HELOANI, R. Modificações neoliberais na universidade pública brasileira: cenário propício para o assédio moral no trabalho. In: GEDIEL, J. A. P (org.). Estado, poder e assédio: relações de trabalho na administração pública. Curitiba: Kairós edições, 2015.

Data de recebimento: $15 / 01 / 2016$

Data de aceite: 05/07/2017

\section{Sobre as autoras:}

Fernanda Iracema Moura Arnaud é Assistente social e Pedagoga, Especialista em Psicologia Educacional, com ênfase em Psicopedagogia (Universidade do Estado do Pará - UEPA); Mestre em Serviço Social (Universidade Federal do Pará - UFPA). Endereço eletrônico: fernandamoura@ig.com.br

Vera Lúcia Batista Gomes é Doutora em Sociologia do Trabalho pela Université de Picardie Jule Verne - Amiens/France. Pós-Doutora em Serviço Social (PPGSS/UFPE) e em Sociologia pelo 
Instituto de Sociologia /Universidade do Porto - Portugal. Docente do Curso de Graduação e PósGraduação em Serviço Social - Universidade Federal do Pará - UFPA. Líder do Grupo de Estudos e Pesquisas Trabalho, Estado e Sociedade na Amazônia/PPGSS-UFPA. Endereço eletrônico: veragomesbelem@hotmail.com 